Document downloaded from:

http://hdl.handle.net/10251/51597

This paper must be cited as:

Velasco De La Fuente, D.; Cesar Leonardo Trujillo Rodríguez; Gabriel Garcerá; Figueres Amorós, E.; Ortega, R. (2013). Photovoltaic Power System With Battery Backup With GridConnection and Islanded Operation Capabilities. IEEE Transactions on Industrial Electronics. 60(4):1571-1581. doi:10.1109/TIE.2012.2196011.

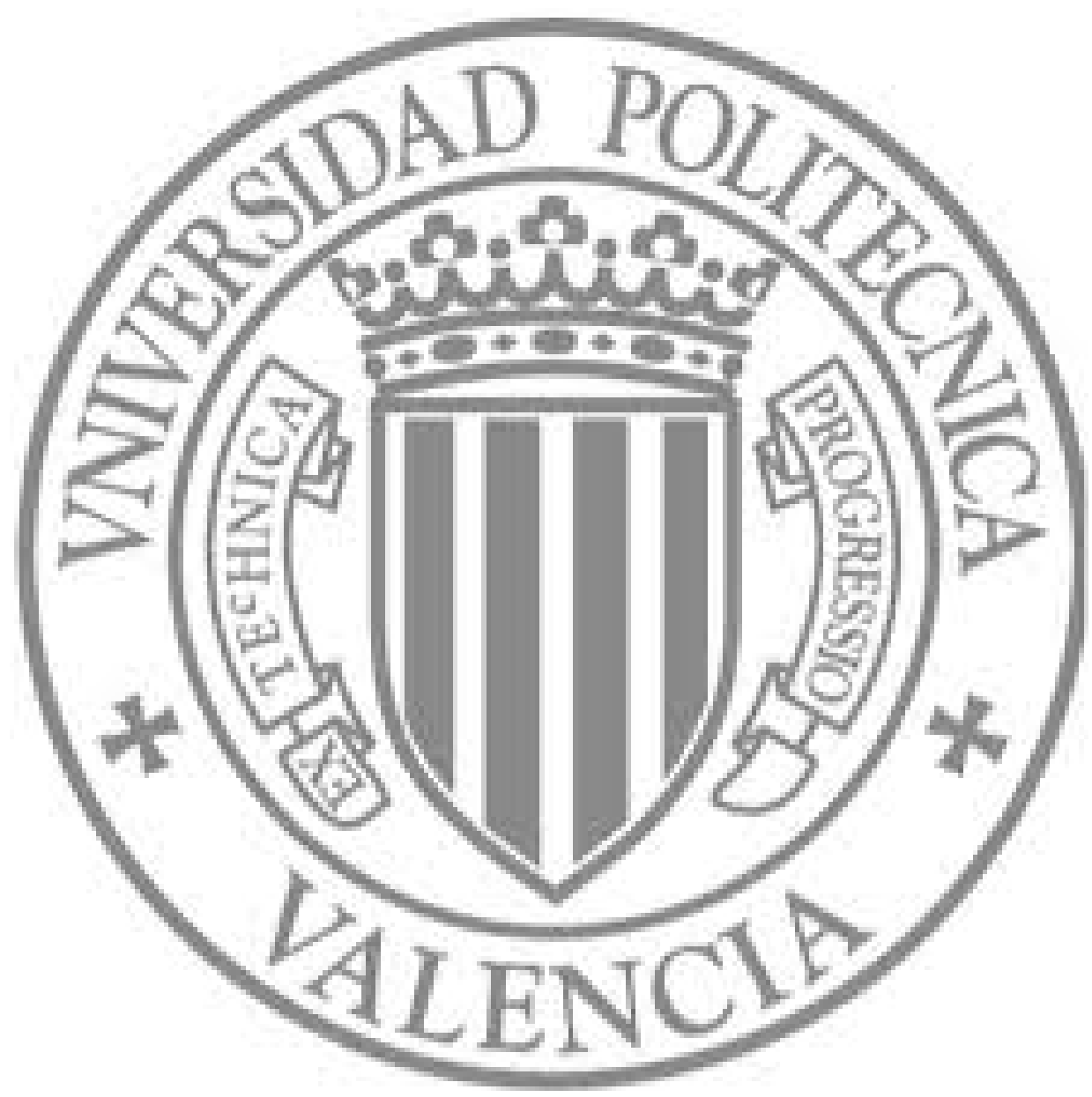

The final publication is available at

Copyright Institute of Electrical and Electronics Engineers (IEEE) 


\section{Photovoltaic Power System with Battery Backup with Grid Connection and Islanded Operation Capabilities}

\begin{abstract}
This paper presents the analysis, design, and experimentation results of a photovoltaic energy management system with battery backup. The proposed system is capable of both grid-connected and islanded operation. The main advantage of the proposed system is that in grid-connected mode the inverter works as a current source in phase with the grid voltage, injecting power to the grid and controlling the DC-link voltage. The DC/DC converter manages the battery charge. In island-mode, the inverter control is reconfigured to work as a voltage source using droop schemes. The DC/DC converter controls the DC-link voltage to enable the maximum power point tracking reference to be followed. An operation protocol is proposed to ensure the quality of the energy supply and minimize energy loss. A battery bank is connected to the DC-link as energy storage for islanded operation mode. The aim of the paper is to show that the proposed system performs correctly, without dangerous transients for the inverter or the loads. Simulation and experimental results on a $3 \mathrm{~kW}$ prototype show the feasibility of the proposed control strategy.
\end{abstract}

\section{INTRODUCTION}

In the recent years, the development of alternative energy sources has become a global priority, giving rise to intensive research about less environmentally polluting renewable sources.

The installation of smaller and distributed power plants has been made possible due to changes in both the power system concept and the economy of scale. The proximity between production and consumption centers has regained importance [1]; and distributed generation (DG) technologies have advanced greatly in recent years.

One way to insert DG systems into an electrical network is through microgrids [2]. A microgrid can be defined as a combination of loads and microsources that provide electric power to a local area. There are currently some important projects on microgrids around the world [3] [4] [5] [6].

The operation of a microgrid offers distinct advantages to customers and utilities, i.e. improved energy efficiency, reduced environmental impact, and greater reliability. One of the most important features of microgrids is that they can independently operate in islanded mode without connection to the distribution system when power system faults or blackouts occur.

Many commercial photovoltaic (PV) inverters work as a current source in grid-connected mode [7] [8]. The control of inverters has developed over time and is now highly efficient for this operational mode.

Several works deal with the correct operation of inverters working in grid-connected and island modes. A possible solution is based on droop schemes. These schemes use P-Q strategies in the inverters to properly share the power delivered to the loads while avoiding critical communication lines. In [9] and [10] the inverters are controlled by means of droop schemes in both operational modes, so that no advantage is taken of control algorithms that inject the inverter output current in phase with the grid voltage (current source algorithms) developed for commercial gridconnected inverters.

In [11] the inverter works as a current source by providing a constant current to the grid. The inverter detects when islanding occurs and changes to voltage source operation. The authors also propose a load-shedding algorithm for intentional islanding and a synchronization algorithm for grid reconnection. During islanding operation, the reference imposed on the inverter voltage controller has a fixed value, so that inverter parallelization for load power sharing is not possible.

In [12] the inverters change their control structure depending on the connection-disconnection status of the microgrid to the main grid. When the main grid is connected, the inverters work as a current source. In an islanding situation, they work as voltage sources connected by robust CAN communications. However, this system requires a correctly operating communications bus and this increases the cost.

In other studies such as [13] and [14] reconfigurable control schemes are proposed, based on a very simple and effective type of control, namely a multiloop linear PI control system. This method uses linear inner and outer PI control loops to regulate the system state variables. However, these papers do not clearly explain how inverters are parallelized when sharing the load power.

There are multiple implementation options for energy storage. Some authors propose an energy storage independent from generators, as in [4] [15] [16]. Another option is to integrate storage and generation in a single system. Parallel integrated systems with a common DC bus are proposed in [17] [18] [19]. This DC bus has a fixed voltage, so that power converters for both generation and battery management are necessary to adequate the voltage and perform the maximum power point tracking (MPPT) of the power sources.

In [20] the proposed system is composed of a photovoltaic generator and a battery bank interconnected by means of a $\mathrm{DC} / \mathrm{DC}$ converter. The inverter and the $\mathrm{DC} / \mathrm{DC}$ converter share the same DC bus. The DC bus voltage is the same as the PV panel output voltage, which is imposed by an MPPT 
algorithm. This system has been designed for stand-alone applications.

This paper shows a reconfigurable control scheme based on multiloop control in both operational modes. In grid connection mode the inverter is controlled as a current source in phase with the grid voltage. When the microgrid becomes isolated from the grid, the inverters change their control configuration, working as voltage sources and using a droop method [9] [21] [22] [23] to share the power demanded by the local loads. The droop method provides a good solution for parallelizing multiple inverters without using communications - as is detailed in the bibliography.

The proposed PV energy system provides energy storage capability and allows maximizing the energy extracted from the PV panels in both operational modes. The system includes a parallel energy storage system composed of a battery bank and a DC/DC converter that ensures the maximum power point (MPP) tracking of the PV source in island operation. Additionally, the proposed control reconfiguration is possible without dangerous transients for the inverter or the loads.

\section{Photovoltaic SYSTEM}

The photovoltaic system under study, shown in Fig. 1, includes a $3 \mathrm{~kW}$ full-bridge single phase inverter and a bidirectional DC/DC converter. The DC/DC is connected to the DC-link at the input of the inverter. The DC/DC converter manages the battery charge-discharge. The DClink voltage, $\mathrm{V}_{\mathrm{DC}}$, is set by a maximum power point tracker (MPPT) in both islanded mode and grid-connected mode. In island mode the MPPT provides a reference voltage to the $\mathrm{DC} / \mathrm{DC}$ converter, so that it regulates $\mathrm{V}_{\mathrm{DC}}$. In grid connected mode the MPPT delivers a reference voltage to the inverter, so that it can perform $V_{D C}$ regulation. The MPPT is implemented by means of a $\mathrm{P} \& \mathrm{O}$ (perturb and observe) algorithm [24], [25]. The MPPT defines the setpoint of the DC-link voltage to extract the maximum output power from the PV panel.

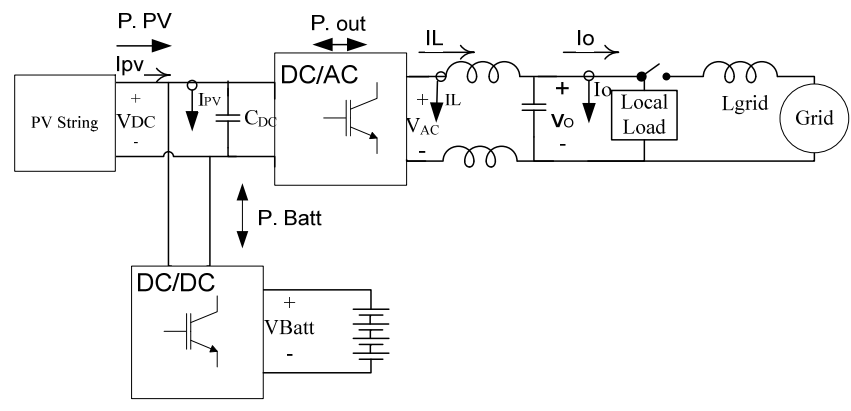

Fig. 1 Block diagram of the PV system under study.

The PV arrangement provides a DC-link voltage of around $V_{D C}=380 \mathrm{~V}$ at the maximum power point (MPP), high enough to inject power to the grid ( $230 V_{R M S}, 50 \mathrm{~Hz}$ ) without a step-up transformer.

To perform the simulations, the PV array has been modelled as a current source that dependent of the incoming irradiance, inserting the I-V curves of the panels as a function of several irradiance levels by means of a table.

\section{A. Single phase inverter}

Fig. 2 depicts the scheme and the control structure of the inverter that has been implemented. A current-controlled H- bridge single-phase inverter with bipolar PWM [26] has been chosen. This kind of inverter is common in gridconnected PV systems [27]. The inverter is fed by a DC programmable source in which the I-V curve of a PV panel has been programmed to emulate an array of 14 series connected PV panels. Table I shows the electrical parameters of the PV inverter under study. The inverter under study is $3 \mathrm{~kW}$ with a switching frequency of $16 \mathrm{kHz}$.

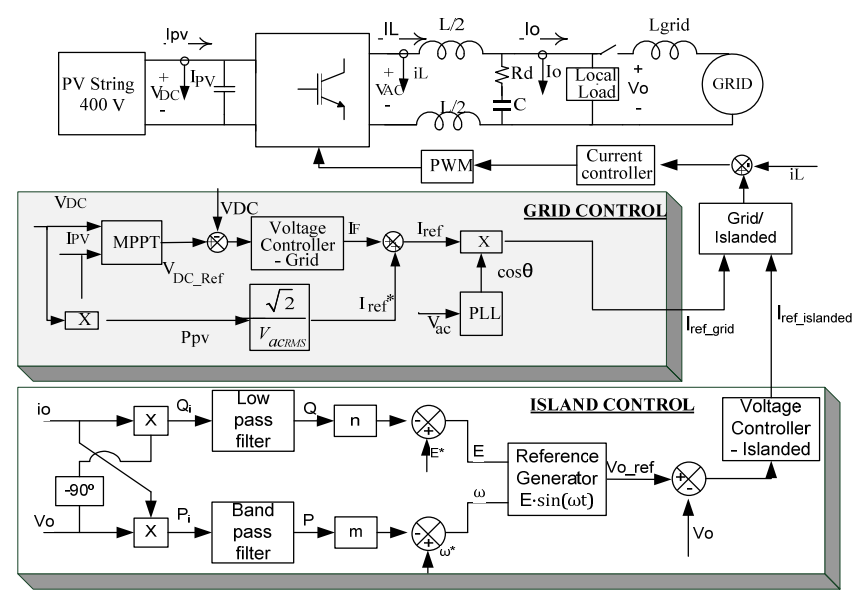

Fig. 2. Control structure of the PV inverter. Al imprimir muchas, de las letras de las cajas "grid control" y "island control" casi no se ven. Aumenta el tamaño.

TABLE I

ELECTRICAL PARAMETERS OF THE INVERTER UNDER STUDY.

\begin{tabular}{|c|c|}
\hline Parameter & Value \\
\hline $\begin{array}{l}\text { Power injected from the PV panels } \\
\left(P_{p v_{-} M P P}\right) \\
\text { DC-link voltage al the MPP }\left(V_{D C_{-} M P P}\right) \\
\text { Inverter output voltage }\left(V_{O_{-} R M S}\right) \\
\text { Fundamental frequency of the inverter } \\
\text { output }\left(f_{g}\right) \\
\text { Inverter inductance }(L) \\
\text { DC-link capacitor }\left(\mathrm{C}_{D C}\right) \\
\text { Inverter output capacitor }(C) \\
\text { Damping resistance }\left(R_{d}\right) \\
\text { Inverter switching frequency }\left(f_{s \text { inv }}\right)\end{array}$ & $\begin{array}{c}3 \mathrm{~kW} \\
380 \mathrm{~V} \\
230 V_{R M S} \pm 10 \% \\
50 \mathrm{~Hz} \\
2.7 \mathrm{mH} \\
2 \mathrm{mF} \\
4.5 \mu \mathrm{F} \\
5 \Omega \\
16 \mathrm{kHz}\end{array}$ \\
\hline
\end{tabular}

\section{B. DC/DC converter.}

To improve the power management in the microgrid, a backup energy storage is included. It consists of a battery bank connected to the inverter DC-link by means of a twoquadrant bidirectional DC/DC converter. The main advantage of this configuration is that the $\mathrm{DC} / \mathrm{DC}$ converter processes only a part of the generated power. This converter performs multiple functions: it serves as a battery charge regulator in grid-connected operation, and a boost converter to deliver energy from the batteries to the inverter when the PV source has insufficient power to feed the local loads in islanded operation. In island mode, the most favorable operating condition occurs when the load power and the PV extracted power agree, i.e., when the DC/DC does not process power. Fig. 3 shows the simplified DC/DC converter power stage and its control structure. Table II shows the electrical parameters of the DC/DC converter under study.

TABLE II

ELECTRICAL PARAMETERS OF THE DC-DC CONVERTER

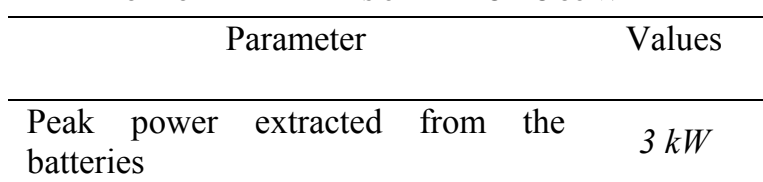


DC-link voltage $\left(V_{D C} M P P\right)$

Battery bank voltage $\left(V_{\text {Batt }}\right)$

Converter inductance $\left(L_{b a t}\right)$

Converter switching frequency $\left(f_{s d c d c}\right) \quad 16 \mathrm{kHz}$

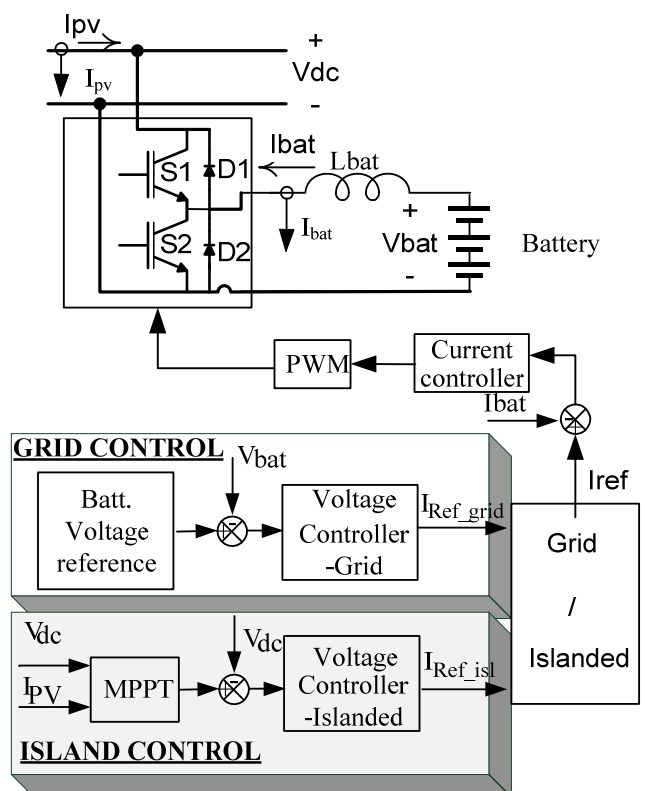

Fig. 3 DC-DC converter schematic and control structure.

The islanded and grid-connected operational modes are explained in the following sections.

\section{DYNAMIC ANALYSIS}

The inverter switches from grid connected mode to island mode by selecting between two current references: $\mathrm{I}_{\text {ref grid }}$ and $\mathrm{I}_{\text {ref }}$ islanded, as depicted in Fig. 2. The method described in [28] is used to detect the islanding condition.

A stability analysis of the converters is shown for both operation modes.

\section{A. PV power system working in grid connected mode}

In grid-connected mode, the $\mathrm{DC}$-link voltage $\left(\mathrm{V}_{\mathrm{DC}}\right)$ control is performed by the inverter, following a reference provided by the MPPT algorithm. A PI controller (voltage controllergrid element in Fig. 2) is used for the inverter voltage loop in this operational mode. A feedforward term, $I_{\text {ref }}{ }^{*}$, expressed by (1), is added to the output of the PI DC-link voltage controller, $\mathrm{I}_{\mathrm{F}}$, yielding the amplitude of the current loop reference, $I_{r e f}$. The term $I_{r e f} *$ is derived from the active power that is being delivered by the PV source [8].

$$
\mathrm{I}_{\mathrm{ref}}^{*}=\frac{P_{P V} \cdot \sqrt{2}}{V_{a c R M S}}
$$

The amplitude $I_{\text {ref }}$ is multiplied by the term $\cos \theta$, provided by a phase locked loop (dqPLL) operating from the grid voltage. The dqPLL is implemented using the synchronous rotating reference frame technique [29], [30]. The angle $\theta$ is that of the fundamental component of the grid voltage.

The current controller was implemented by means of a harmonics compensator [31] in order to comply with the standard IEEE 929-2000 [32] in terms of both the current THD (THDi) and the individual limits of harmonics.
Fig. 4 and Fig. 5 show the control loop block diagrams in grid-connected operational mode for the inverter and the DC/DC converter, respectively.

In Table III, the expressions of the transfer functions of interest for the control of the PV power system in grid connected mode are summarized.

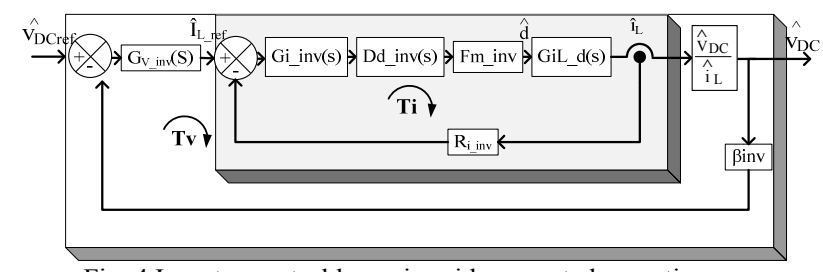

Fig. 4 Inverter control loops in grid connected operation.

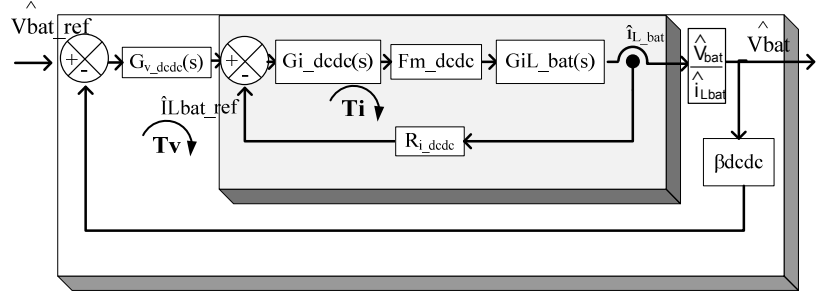

Fig. 5 DC/DC converter control loops in grid connected operation. En las figuras 4 y 5 los nombres de algunos bloques son casi ilegibles después de imprimir. Deberías simplificar los nombres de cada bloque para poder aumentar el tamaño de letra. Una estrategia es poner subíndice 1 a los bloques del lazo del inversor y subíndice2 a los del DCDC. Por ejemplo, $\mathrm{G}_{\mathrm{V} \text { inv }}(\mathrm{s})$ podría pasar a llamarse $\mathrm{G}_{\mathrm{V} 1}(\mathrm{~s})$ y su cajita hacerla más alta. $\mathrm{G}_{\mathrm{iL} \_\mathrm{d}}(\mathrm{s})$ podría pasar a llamarse $H_{i 1}(s), G_{i \_ \text {inv }}(s)$ podría pasar a $G_{I 1}(s)$. Dd_inv(s)

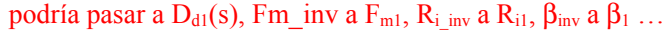

$\mathrm{G}_{\mathrm{v} \text {-dddc }}(\mathrm{s})$ podría pasar a $\mathrm{G}_{\mathrm{V} 2}(\mathrm{~s}) . \mathrm{Gi}_{-} \mathrm{dcdc}(\mathrm{s})$ a $\mathrm{G}_{\mathrm{I} 2}(\mathrm{~s}), \mathrm{GiL}$ bat(s) a $\mathrm{H}_{2}(\mathrm{~s})$, etc..

Seguro que puedes idear una nomenclatura completamente nueva y ser consistente en el resto del texto (tablas con las f.d.t's)

TABLE III

TRANSFER FUNCTIONS OF INTEREST FOR CONTROL OF THE PV SYSTEM IN GRID-CONNECTED MODE.

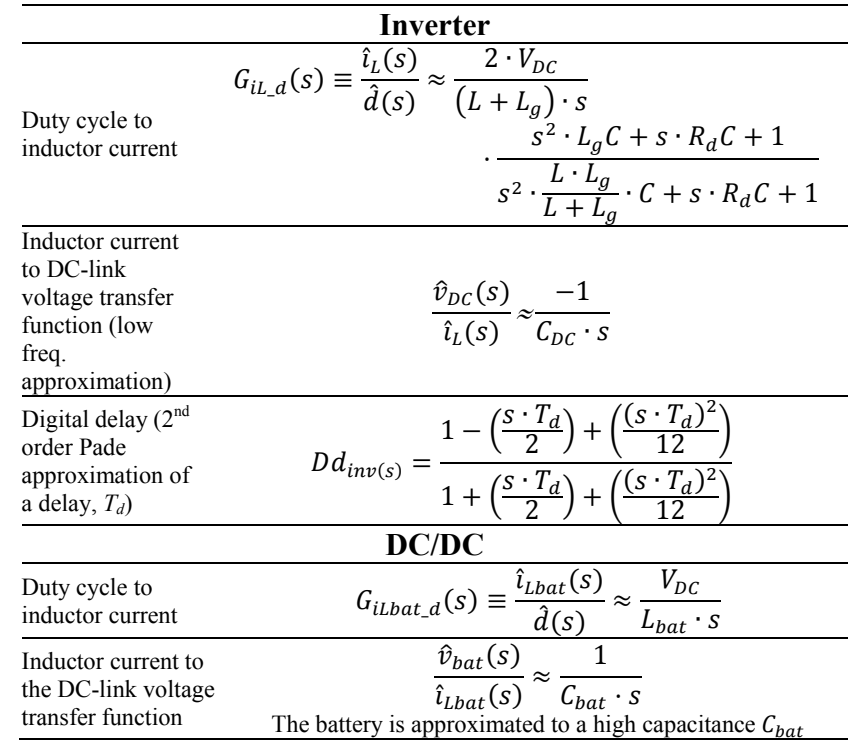

Table IV shows the expressions of the chosen controllers for the inverter and DC/DC converter under study in gridconnected mode, along with the corresponding crossover frequencies $\left(\mathrm{f}_{\mathrm{C}}\right)$ and phase margins $(\mathrm{PM})$. 
TABLE IV

SUMMARY OF THE EXPRESSIONS OF THE CHOSEN CONTROLLERS, CROSSOVER FREQUENCIES AND PHASE MARGINS IN GRID CONNECTION MODE.

\begin{tabular}{|c|c|c|c|}
\hline \multicolumn{4}{|c|}{ Controllers (grid mode) } \\
\hline & Inverter & $\mathbf{f}_{\mathrm{C}}$ & $\mathbf{P M}$ \\
\hline $\begin{array}{l}\text { Current } \\
\text { controller }\end{array}$ & $\begin{array}{c}G_{i_{-} I N V}=K_{p}+\frac{k_{h} \cdot B_{h} \cdot s}{s^{2}+B_{h} \cdot s+\omega_{h}{ }^{2}}= \\
100 \cdot(2 \pi) \cdot s\end{array}$ & \multirow[t]{2}{*}{$1.35 \mathrm{kHz}$} & \multirow[t]{2}{*}{$58.5^{\circ}$} \\
\hline & $=4 . \angle Z+\overline{s^{2}+2 \pi \cdot s+(100 \pi)^{2}}$ & & \\
\hline $\begin{array}{l}\text { Voltage } \\
\text { controller }\end{array}$ & $G_{v_{-} I N V}=K \cdot \frac{s+a}{s(s+b)}=$ & $12.6 \mathrm{~Hz}$ & $79^{\circ}$ \\
\hline & $=-5 \angle 8 \cdot \overline{s(s+1000)}$ & & \\
\hline $\begin{array}{l}\text { PWM } \\
\text { modulator } \\
\text { gain }\end{array}$ & $F_{m_{-} I N V}=1$ & & \\
\hline $\begin{array}{c}\text { Voltage } \\
\text { sensor gain }\end{array}$ & $\beta_{I N V}=0.06$ & & \\
\hline $\begin{array}{c}\text { Current } \\
\text { sensor gain }\end{array}$ & $R_{i_{-} I N V}=0.02$ & & \\
\hline \multirow{3}{*}{$\begin{array}{l}\text { Digital delay } \\
\text { of one } \\
\text { switching } \\
\text { period } \\
\end{array}$} & & & \\
\hline & $T_{d}=62.5 \mu \mathrm{s}$ & & \\
\hline & DC/DC & $\mathbf{f}_{\mathrm{C}}$ & $\mathbf{P M}$ \\
\hline $\begin{array}{c}\text { Current } \\
\text { controller }\end{array}$ & $G_{i_{-} d c d c}=3500 \cdot \frac{1+0.0028 \cdot s}{s}$ & $1.05 \mathrm{kHz}$ & $121^{\circ}$ \\
\hline \multirow{2}{*}{$\begin{array}{l}\text { Voltage } \\
\text { controller }\end{array}$} & \multirow{2}{*}{$G_{v_{-} d c d c}=0.5 \cdot \frac{1+0.0076 \cdot s}{s}$} & \multirow{2}{*}{$12 \mathrm{~Hz}$} & \multirow{2}{*}{$112^{\circ}$} \\
\hline & & & \\
\hline $\begin{array}{l}\text { PWM } \\
\text { modulator } \\
\text { gain }\end{array}$ & $F_{m_{-} d c d c}=1$ & & \\
\hline $\begin{array}{c}\text { Voltage } \\
\text { sensor gain }\end{array}$ & $\beta_{d c d c}=0.06$ & & \\
\hline $\begin{array}{c}\text { Current } \\
\text { sensor gain }\end{array}$ & $R_{i_{-} d c d c}=0.015$ & & \\
\hline
\end{tabular}

Fig. 6 and Fig. 7 show the Bode plots of the current $\left(\mathrm{T}_{\mathrm{i}}\right)$ and voltage $\left(\mathrm{T}_{\mathrm{v}}\right)$ loop gains of the inverter and $\mathrm{DC} / \mathrm{DC}$ converter, respectively, in grid-connected mode. The Bode plots predict the stability of the PV power system in this operational mode.

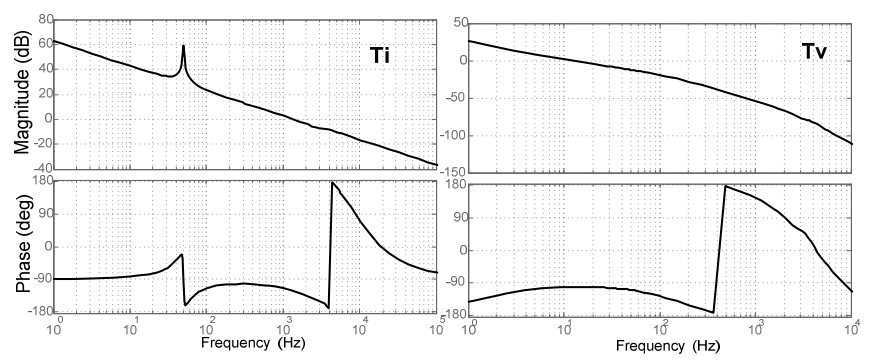

Fig. 6. Bode plots of the inverter loop gains, $T_{i}(s)$ and $T_{v}(s)$, in grid connected operation mode.
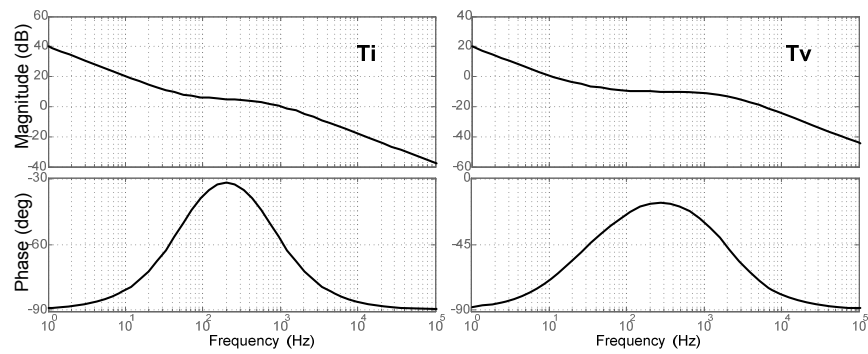

Fig. 7. Bode plots of the DC/DC converter loop gains, $\mathrm{Ti}(\mathrm{s})$ and $\mathrm{Tv}(\mathrm{s})$, in grid connected operation mode.

\section{B. PV power system working in island mode}

In island mode, the inverter feeds the local loads, producing a similar load voltage waveform as in the gridconnected situation. The inverter works as an $\mathrm{AC}$ voltage source feeding local loads. Therefore, it is necessary to have some energy storage element such as a battery, because the PV panels may not always be able to meet the power demand of the local loads.

It should be taken into account that the power delivered by the inverter must match the load power consumption. For this reason, it is necessary to find the reference of the inverter output voltage ( $\mathrm{V}_{\mathrm{o}_{-} \text {ref }}$ in Fig. 2$)$ in terms of the active power and reactive power consumed by the loads. The method used to determinate this voltage reference is the droop method [33], as depicted in Figure 2. In the system under study an only PV inverter has been considered, being the goal of our research the change from grid connected mode to island mode with a battery as additional energy storage, not the droop method in itself. As only one inverter in islanded mode has been studied, the droop method is not necessary. Nevertheless, the inverter control has been developed to work in a micro-grid environment, in parallel with other inverters. Therefore, the analysis and the experimental results have been obtained with the full algorithm working (droop + inverter current and voltage loops). The voltage reference of the inverter output voltage controller (voltage controller-islanded element in Fig. 2) is synthesized by means of the droop scheme studied in [9]. In island operation mode, the DC-link voltage is controlled by the battery side DC-DC converter following a reference set by the MPPT algorithm. La figura que viene debe de estar repetida.

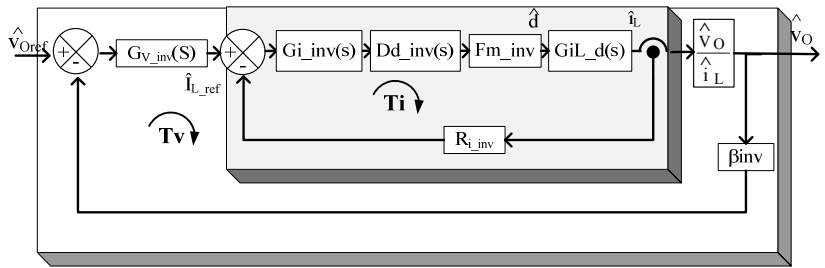

Fig. 8 and 9 show the inverter and DC/DC converter control loops for island operation, respectively. iiiAquí hay un error. Por favor comprueba las cosas. Falta el pie de la figura, y lo que has puesto en lugar del pie es una frase $\mathrm{ii}$

In Table IV, the transfer functions of interest for the control of the system in island mode are summarized. The term $\mathrm{Z}_{\mathrm{L}}(\mathrm{s})$ stands for the impedance of the local load in island mode.

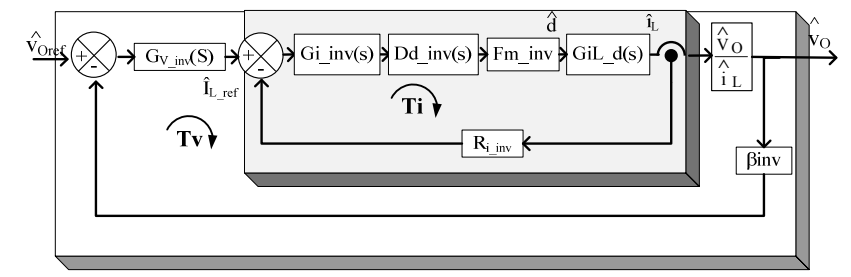

Fig. 8 Inverter control loops in island operation

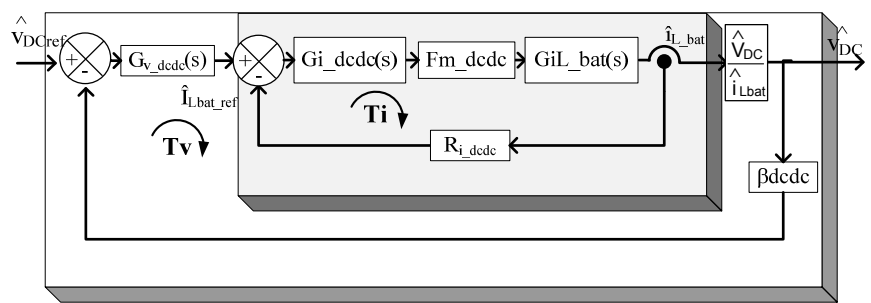

Fig. 9 DC/DC converter control loops in island operation Seguro que puedes idear una nomenclatura completamente nueva y ser consistente en el resto del texto (tablas con las f.d.t's). Usa una nomenclatura como la que te propongo para las figuras 4 y 5 . 
TABLE V

TRANSFER FUNCTIONS OF INTEREST FOR CONTROL OF THE SYSTEM IN ISLAND MODE.

\begin{tabular}{|c|c|}
\hline \multicolumn{2}{|r|}{ Inverter } \\
\hline $\begin{array}{l}\text { Duty cycle to } \\
\text { inductor current }\end{array}$ & $\begin{array}{c}G_{i L_{-} d}(s) \equiv \frac{\hat{l}_{L}(s)}{\hat{d}(s)}=2 \cdot V_{i} \cdot \frac{\operatorname{NUM}(s)}{\operatorname{DEN}(s)} \\
\operatorname{NUM}(s)=\left(s^{2} L_{g} C+s \cdot C \cdot\left(R_{d}+Z_{L}(s)\right)+1\right) \\
\operatorname{DEN}(s)=s^{3} L L_{g} C+s^{2} C\left(L R_{d}+L Z_{L}(s)\right. \\
\left.+L_{g} R_{d}\right)+ \\
+s \cdot\left(L+L_{g}+Z_{L}(s) R_{d} C\right)+Z_{L}(s)\end{array}$ \\
\hline $\begin{array}{l}\text { Inductor current to } \\
\text { output voltage }\end{array}$ & $\begin{array}{l}G_{v o_{-} i L}(s) \equiv \frac{\hat{v}_{O}(s)}{\hat{\imath}_{L}(s)} \\
=\frac{\left(1+s \cdot R_{d} C\right) \cdot\left(L_{g} \cdot s+Z_{L}(s)\right)}{s^{2} \cdot L_{g} C+s \cdot C \cdot\left(R_{d}+Z_{L}(s)\right)+1}\end{array}$ \\
\hline $\begin{array}{l}\text { Digital delay }\left(2^{\text {nd }}\right. \\
\text { order Pade } \\
\text { approximation of a } \\
\left.\text { delay, } T_{d}\right)\end{array}$ & $D_{d_{-} i n v}(s)=\frac{1-\left(\frac{s \cdot T_{d}}{2}\right)+\left(\frac{\left(s \cdot T_{d}\right)^{2}}{12}\right)}{1+\left(\frac{s \cdot T_{d}}{2}\right)+\left(\frac{\left(s \cdot T_{d}\right)^{2}}{12}\right)}$ \\
\hline \multicolumn{2}{|r|}{$\mathrm{DC} / \mathrm{DC}$} \\
\hline $\begin{array}{l}\text { Duty cycle to } \\
\text { inductor current }\end{array}$ & $\begin{array}{c}G_{i-d}(s)=\left.\frac{\hat{\mathrm{i}}_{\text {Lbat }}}{\hat{d}}\right|_{\widehat{V}_{D C}=0}= \\
=\frac{V_{D C}+(1-D) \cdot Z_{D C}(s) \cdot I_{L b a t}}{s \cdot L+(1+D)^{2} * Z_{D C}(s)}\end{array}$ \\
\hline $\begin{array}{l}\text { Inductor current to } \\
\text { the DC-link voltage } \\
\text { transfer function }\end{array}$ & $\begin{array}{c}\frac{\hat{V}_{D C}}{\hat{\imath}_{L b a t}}= \\
=\frac{V_{D C} \cdot Z_{D C}(s) \cdot(1-D)-Z_{D C}(s) \cdot L \cdot s \cdot I_{L b a t}}{V_{D C}+(1-D) \cdot Z_{D C}(s) \cdot I_{L b a t}}\end{array}$ \\
\hline
\end{tabular}

Table VI shows the expressions of the chosen regulators for both the inner current loop and the outer voltage loop, along with the corresponding crossover frequencies $\left(f_{C}\right)$ and phase margins (PM) for the inverter and DC/DC converter in island mode.

Fig. 10 and Fig. 11 show the Bode plots of the current $\left(\mathrm{T}_{\mathrm{i}}\right)$ and voltage $\left(\mathrm{T}_{\mathrm{v}}\right)$ loop gains of the inverter and $\mathrm{DC} / \mathrm{DC}$ converter, respectively, in island mode. The Bode plots predict the stability of the PV power system in this operation mode.

TABLE VI

SUMMARY OF THE EXPRESSIONS OF THE CHOSEN CONTROLLERS, CROSSOVER FREQUENCIES AND PHASE MARGINS IN ISLAND MODE.

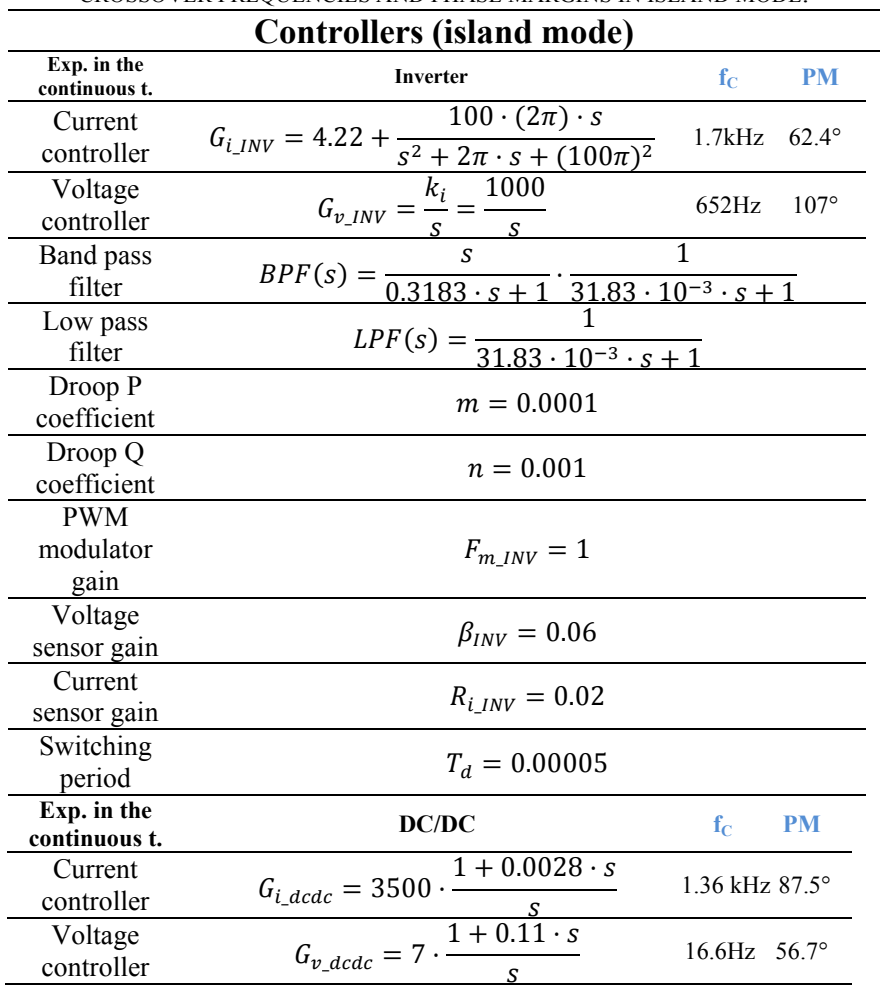

\begin{tabular}{cc}
\hline $\begin{array}{c}\text { PWM } \\
\text { modulator } \\
\text { gain }\end{array}$ & $F_{m_{-} d c d c}=1$ \\
\hline $\begin{array}{c}\text { Voltage } \\
\text { sensor gain }\end{array}$ & $\beta_{d c d c}=0.06$ \\
\hline $\begin{array}{c}\text { Current } \\
\text { sensor gain }\end{array}$ & $R_{i_{-} d c d c}=0.015$ \\
\hline
\end{tabular}
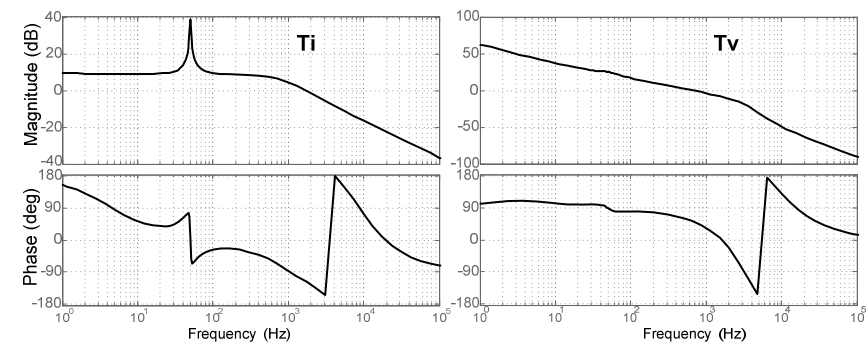

Fig. 10. Bode plots of the inverter loop gains, $T_{i}(s)$ and $T_{v}(s)$, in island operation mode.

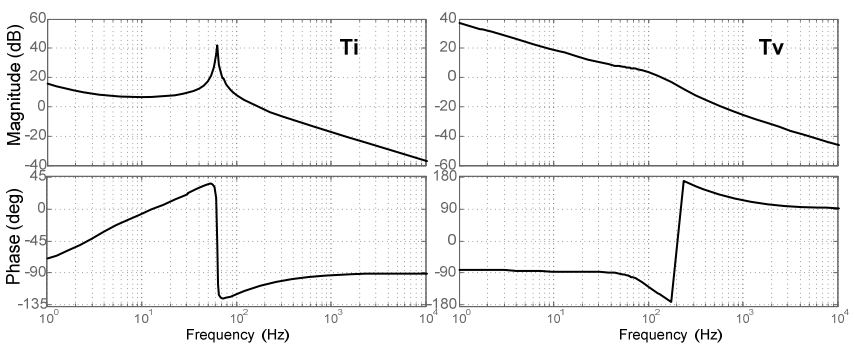

Fig. 11. Bode plots of the DC/DC converter loop gains, $T_{i}(s)$ and $T_{v}(s)$, in island operation mode.

To avoid abrupt transitions from one operation mode to another, it is necessary to equalize the initial conditions of the current controllers of both the inverter and the DC/DC converter before the change. It should be pointed out that when switching from one mode to the other the same transfer functions of the current controllers are used [34].

\section{ENERGY MANAGEMENT}

Fig. 12 and Fig. 13 depict the proposed energy management protocol in grid-connected operation and in islanded operation, respectively.

When the grid is connected, the power needed to charge the batteries can be extracted from the PV array and from the grid. Fig. 12 illustrates a possible scenario in this operational mode regarding the power delivered to the batteries at a constant available power from the PV source. At the beginning, the available PV power is less than the necessary battery charge power and the inverter takes the supplementary energy from the grid $\left(\mathrm{P}_{\text {out }}<0\right)$. When the battery charge power decreases, the inverter starts to inject power to the grid $\left(\mathrm{P}_{\text {out }}>0\right)$. After the end of charge all the available PV energy is injected to the grid $\left(\mathrm{P}_{\mathrm{pv}}=\mathrm{P}_{\mathrm{out}}\right)$. 


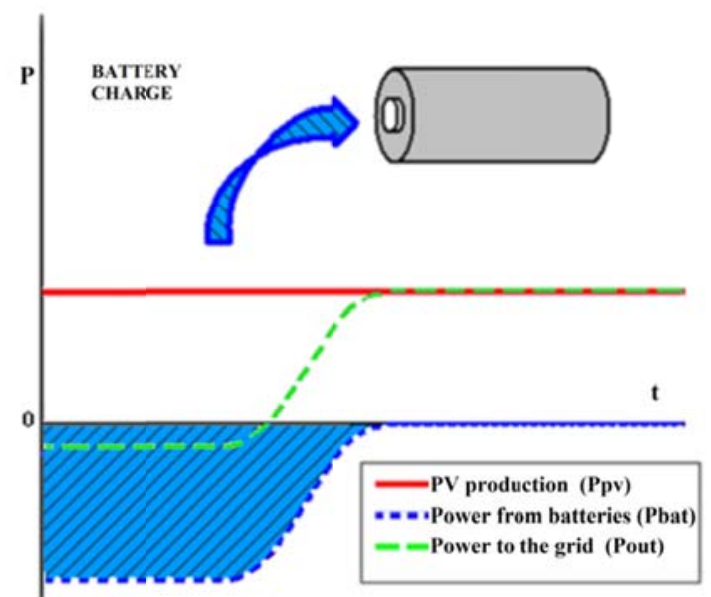

Fig. 12. Energy management protocol in grid connected operation

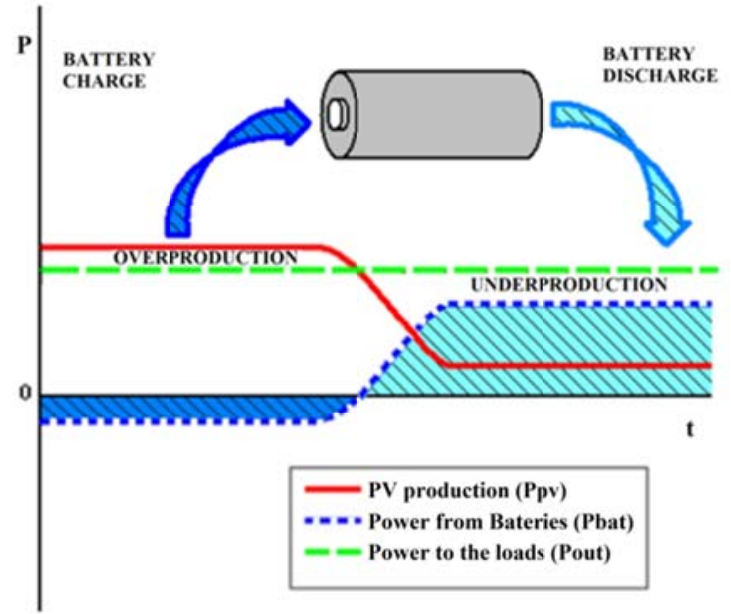

Fig. 13. Energy management protocol in islanded mode operation

Fig. 13 depicts a possible scenario in islanded operation mode. In this mode, the batteries work as an energy backup - necessary if available PV power is less than the load power demand. The batteries obtain energy from the PV source when the generated power is higher than that required by the loads. When the power required by the loads is higher than that of PV generation, the batteries deliver the necessary additional power.

\section{Simulation Results}

This section presents simulation results of the above system. These simulations were conducted using PSIM ${ }^{\mathrm{TM}}$ software [35] and tested on the PV inverter and grid previously described in Section II. The grid inductance value chosen for simulations is $L_{\text {grid }}=270 \mu \mathrm{H}$.

In the simulations the following nomenclature has been used:

- $\mathrm{P}_{\text {out }}$ : power delivered by the inverter to the AC side. When $\mathrm{P}_{\text {out }}<0$, the inverter is delivering power to the batteries. $\mathrm{P}_{\text {out }}>0$ means power flow from the inverter to the AC side, either to the grid (grid mode) or to local loads (islanded mode).

- $\mathrm{P}_{\text {batt }}$ : power delivered by the batteries. When $\mathrm{P}_{\text {batt }}<0$, the batteries are being charged. $\mathrm{P}_{\text {batt }}>0$ means battery charge.

- $\mathrm{P}_{\mathrm{pv}}$ : power delivered by the PV source. It holds that $P_{p v} \geq 0$.
From the above definition of powers it holds: $\mathrm{P}_{\mathrm{pv}}+\mathrm{P}_{\text {batt }}=\mathrm{P}_{\text {out }}$.

Fig. 14 shows an irradiance variation $\left(\mathrm{P}_{\mathrm{pv}}\right.$ is increased from $500 \mathrm{~W}$ to $2 \mathrm{~kW}$ ), followed by a variation of the battery charge power $\left(\mathrm{P}_{\text {batt }}\right.$ varies from $-880 \mathrm{~W}$ to $\left.0 \mathrm{~W}\right)$ power in grid-connected operation. The upper two graphs show the evolution of the PCC voltage and the AC current injected by the inverter. The third graph shows the evolution of the battery output current $\left(\mathrm{I}_{\mathrm{bat}}<0\right.$ means that the batteries are being charged). The fourth graph shows the DC-link voltage evolution. The bottom graph shows the evolution of the power delivered by the inverter and batteries.

In this operational mode, the DC-link voltage reference is established by the MPPT algorithm and the inverter follows this reference. At the beginning, the inverter takes energy from the grid to track the DC-link voltage level and to ensure the required charge level. Note the $180^{\circ}$ phase shift between the PCC voltage and the grid injected current in the initial situation, while $\mathrm{P}_{\text {out }}<0$. The end of the charge is noticeable when the system stops its energy injection to the battery.
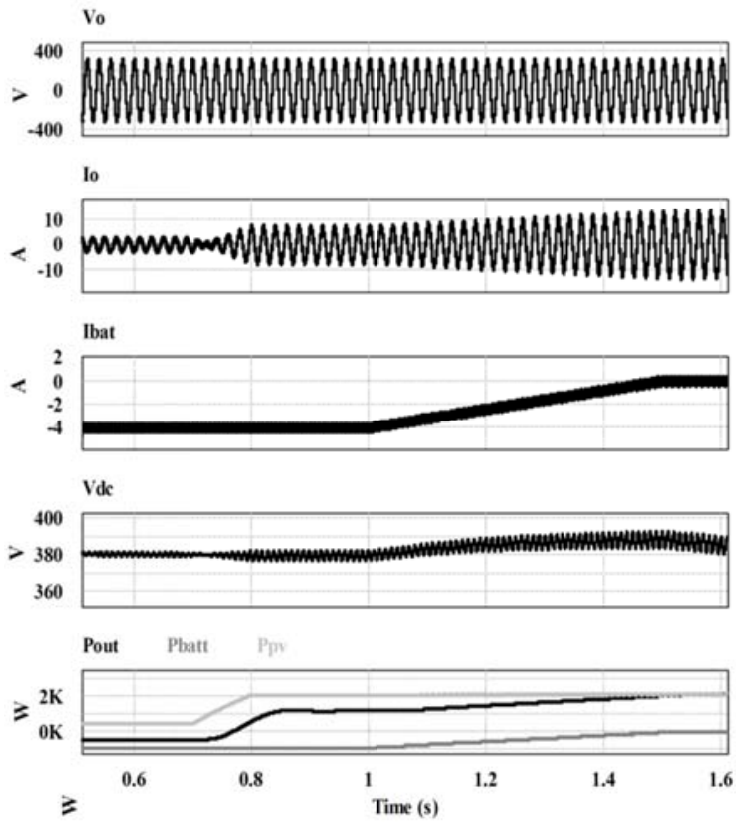

Fig. 14. Simulation of an irradiance wariation followed by a battery charge variation in grid connected mode.

Fig. 15 shows the response of the system to load steps $\left(\mathrm{P}_{\text {out }}=1 \mathrm{~kW} \rightarrow 1.7 \mathrm{~kW} \rightarrow 2.4 \mathrm{~kW} \rightarrow 1.7 \mathrm{~kW}\right.$, resistive load) working in islanded mode at a constant PV power $\left(\mathrm{P}_{\mathrm{pv}}=1.8\right.$ $k W$ ). The inverter output voltage is unaffected by the load step. Note that when $\mathrm{P}_{\mathrm{bat}}<0$, the batteries are being charged; whereas when this power is positive, the batteries deliver the needed supplementary power to the loads. The inverter output power decreases and increases depending on the load power, whereas the PV output power and the DC-link voltage remains constant. The battery bank supplies or absorbs the necessary power to keep a constant DC-link voltage, tracking the MPP of the PV panel. 


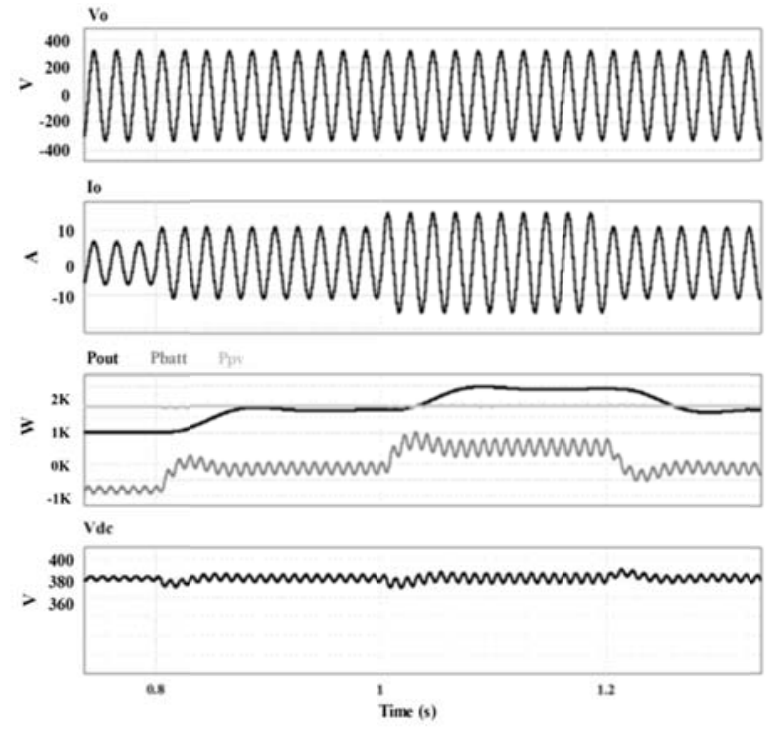

Fig. 15. Simulations in island mode. Resistive load variations at a constant irradiation level.

Fig. 16 shows the transition from grid-connected mode to island mode at a constant irradiance of the PV array $\left(\mathrm{P}_{\mathrm{pv}}=1200 \mathrm{~W}\right)$. After the islanding, the local load power demand (1500 $W$, resistive load) is higher than the PV source generated power and the batteries provide the difference. Note that the inverter output current produces a minimum variation of the PCC voltage in the transition to island mode. The fifth graph depicts the instant in which islanding occurs at $\mathrm{t}=0.5 \mathrm{~s}$.

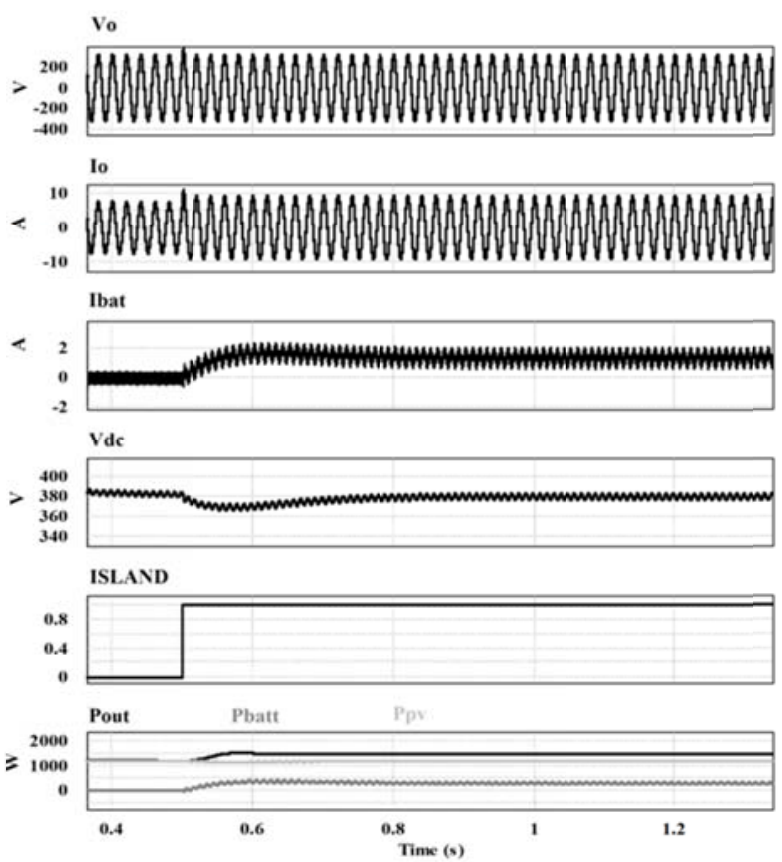

Fig. 16. Transition from grid connected mode to island mode at a constant $\mathrm{P}_{\mathrm{pv}}$. The local load is resistive, $1500 \mathrm{~W}$.

Fig. 17 shows the transition from grid-connected mode to island mode with a nonlinear local load at a constant irradiance $\left(\mathrm{P}_{\mathrm{pv}}=800 \mathrm{~W}\right)$. The nonlinear load consists of a single-phase bridge diode rectifier with a capacitive filter of $C_{F}=170 \mu F$ with a resistive load $R=55 \Omega$. The crest factor for this rectifier is $C F=2.3$ with an apparent power of
$S_{\text {out }}=1800 \mathrm{VA}$ (power factor, $\mathrm{PF}=0.67 \%$ ) when connected to an ideal $230 V_{R M S}, 50 \mathrm{~Hz}$ supply.

After the islanding, the local load power demand $\left(\mathrm{P}_{\text {out }}=\right.$ $1300 \mathrm{~W}$ ) is higher than the PV source generated power, and the batteries provide the difference. The plots are similar to those in Fig. 16. The THDv in island operation is $6.8 \%$.
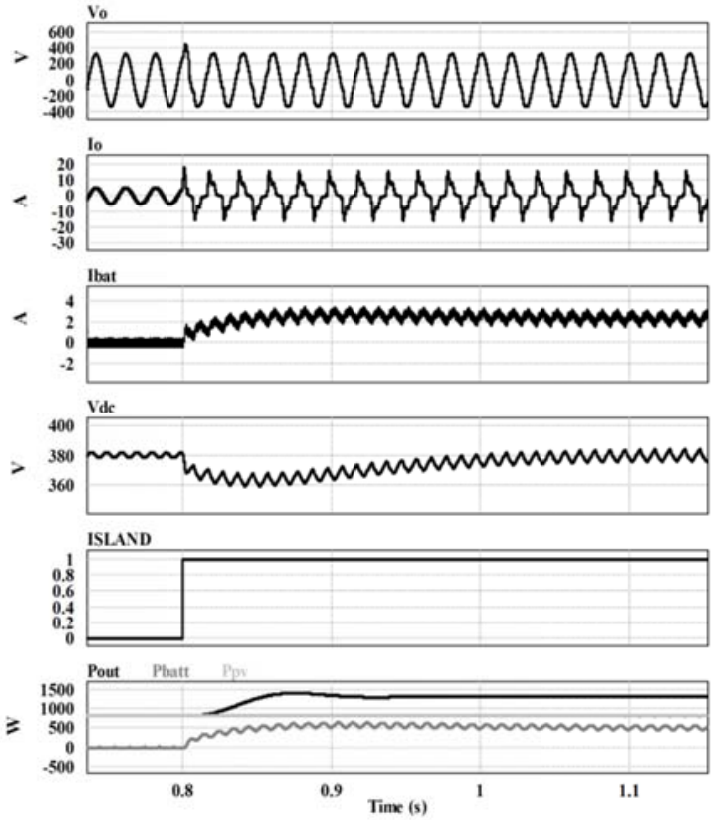

Fig. 17 Transition from grid connected mode to island mode at a constant $\mathrm{P}_{\mathrm{pv}}=800 \mathrm{~W}$. The local load is nonlinear with $\mathrm{CF}=2.3, \mathrm{P}_{\text {out }}=1300 \mathrm{~W}, \mathrm{PF}=0,67$ $\%$

Fig. 18 shows the simulation of a transition from island mode to grid-connected mode. This transition is produced after the inverter output phase synchronization with the grid phase [36]. The power demanided by the local load $(2.1 \mathrm{~kW}$, resistive $)$ is higher than the available $\mathrm{PV}$ power $\left(\mathrm{P}_{\mathrm{pv}}=1.2\right.$ $k W)$. Before the transition, the batteries provide the difference. In a smooth transition, there is a soft transient in the DC-link voltage. After the transition, the inverter works as a current source in phase with the grid voltage.
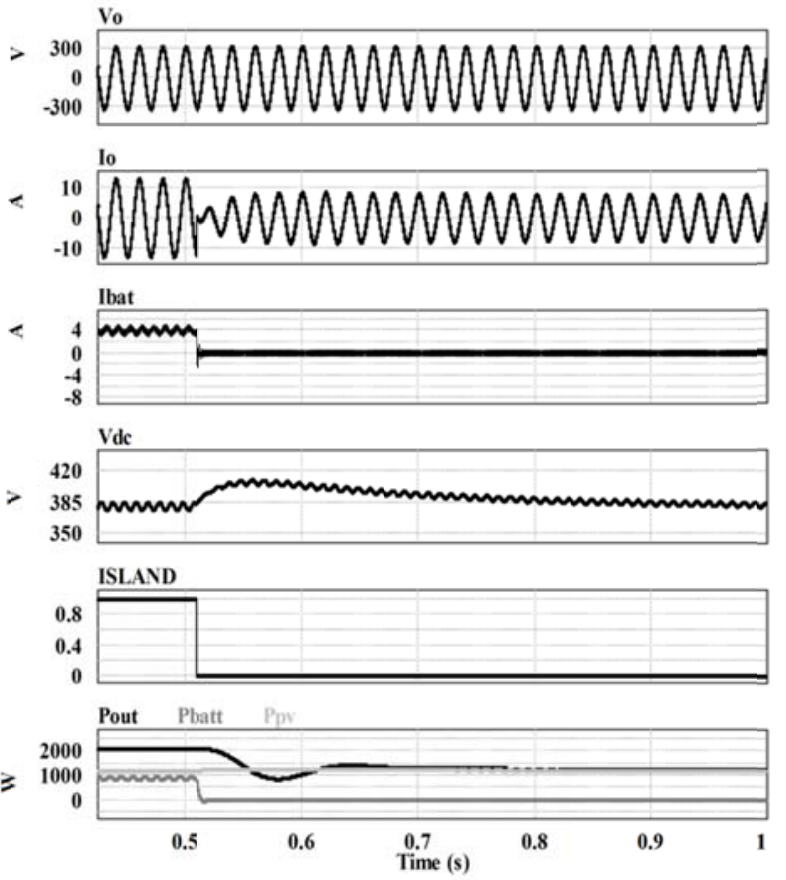

Fig. 18. Transition from island mode to grid-connected mode. 


\section{EXPERIMENTAL RESULTS}

The PV system under study has been tested using an experimental setup in which an I-V curve of a commercial PV array has been programmed on a controllable DC source XANTREX XDC 600-10. The parameters of the experimental inverter are shown in Table I, and the parameters of the DC/DC converter in Table II. The control runs on a general-purpose board designed for the Texas Instruments DSP TMS320F28335 at a sampling frequency of $32 \mathrm{kHz}$ for both the $\mathrm{DC} / \mathrm{DC}$ converter and the inverter. The grid voltage is $230 \mathrm{~V}_{R M S}, 50 \mathrm{~Hz}$. The battery bank was emulated by means on a controllable DC source AMREL SPS 800-12 DO13 connected to power resistors that enable the power flow from the DC-link to the emulated battery bank $\left(\mathrm{P}_{\text {bat }}<0\right)$.

Fig. 19 shows the system behavior in island mode with resistive load steps $\left(\mathrm{P}_{\text {out }}=1202 \mathrm{~W} \rightarrow 1442 \mathrm{~W} \rightarrow 1202 \mathrm{~W}\right)$ at a constant irradiation level $\left(\mathrm{P}_{\mathrm{pv}}=1300 \mathrm{~W}\right)$. The upper two graphs show the evolution of the PCC voltage and the current injected by the inverter to the loads. The third graph shows the evolution of the current injected from the batteries ( $I_{b a t}$ in Fig. 3). The fourth graph depicts the evolution of the DC-link voltage. The DC/DC converter keeps the DC-link voltage following its reference regardless of the inverter output power.

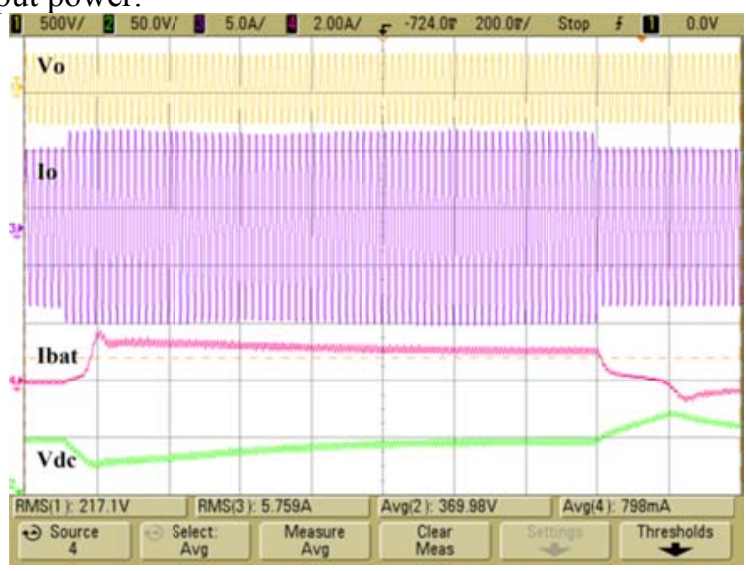

Fig. 19. Transient response for resistive load steps in island mode. Inverter output voltage (Vo, 500V/div), inverter output current to resistive load step (Io, 5A/div), battery output current (Ibat, 2A/div), and DC-link voltage (Vdc, $50 \mathrm{~V} / \mathrm{div})$. Time scale $=200 \mathrm{~ms} / \mathrm{div}$.

Fig. 20 shows the experimental results of the transition from grid-connected mode to island mode. The upper two graphs show the evolution of the PCC voltage and the current injected by the inverter. The third graph shows the battery output current. The fourth graph depicts the evolution of the DC-link voltage. The bottom graph shows the instant at which islanding occurs. The local load power demand (resistive, $1202 \mathrm{~W}$ ) is higher than the power generated by the PV source $(1140 \mathrm{~W})$, and the batteries provide the difference. The system keeps a constant DC-link voltage. It is observed that in the mode transition, the inverter output current produces a small variation of PCC voltage and DC-link voltage. A smooth transient between both operational modes is noticeable.

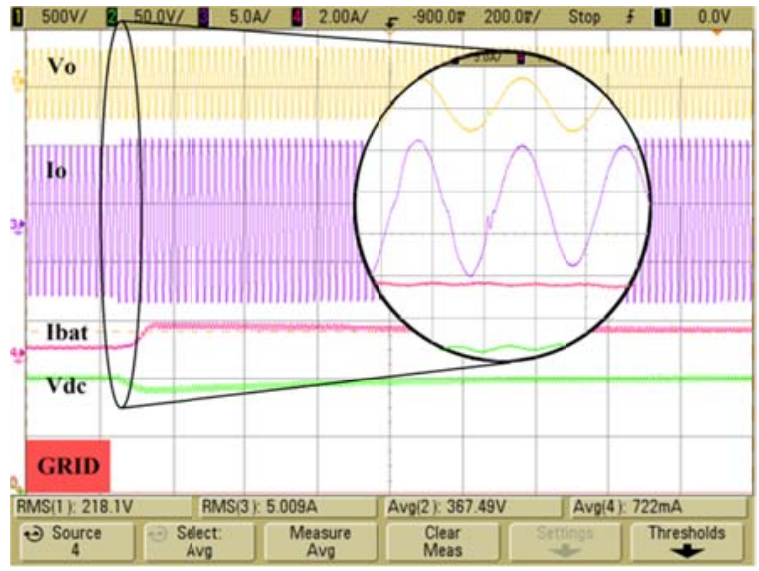

Fig. 20. Experimental results of the transition from grid connected mode to island mode. After the islanding, the power demanded by the local load is higher than the available PV power. Inverter output voltage (Vo, 500V/div) and inverter output current (Io, 5A/div), output battery current (Ibat,

1A/div), DC-link voltage (Vdc 20V/diiv) and islanding signal (GRID). Time scale $=200 \mathrm{~ms} / \mathrm{div}$.

To implement a soft transition from island mode to gridconnected mode, it is necessary to synchronize the inverter output phase and the grid phase. Fig. 21 shows the experimental results of the synchronization algorithm. When both phases match, the grid connection circuit breaker can be reclosed. Synchronization is achieved in about $800 \mathrm{~ms}$.

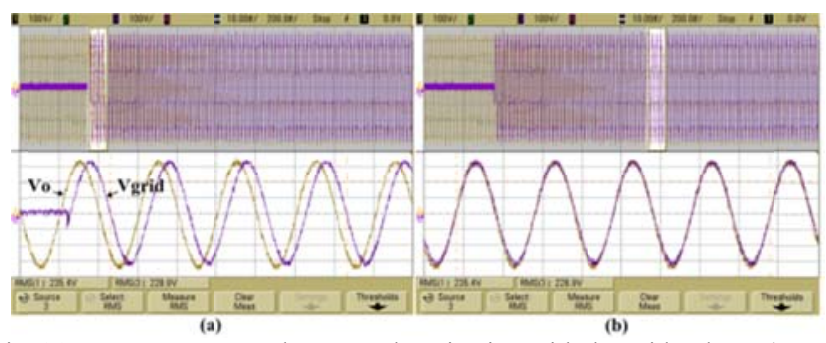

Fig. 21. Inverter output voltage synchronization with the grid voltage (top, $100 \mathrm{~V} / \mathrm{div}$ ). Detail of the synchronization signals. (a) Start of the synchronization and (b) synchronized signals. Time scale $=(200 \mathrm{~ms} / \mathrm{div}$. top $)$ (10ms/diw. bottom)

Fig. 22 shows the waveforms of the smooth transition between island mode and grid connected mode. Once the grid and the inverter voltages are synchronized, the grid circuit breaker is reclosed. This transition has no significant voltage or current transients. The inverter is loaded with a resistive load of $1200 \mathrm{~W}$ in island mode. After the transition, the inverter injects the power available in the emulated PV source into the grid, in this case $P_{p v}=1000 \mathrm{~W}$.

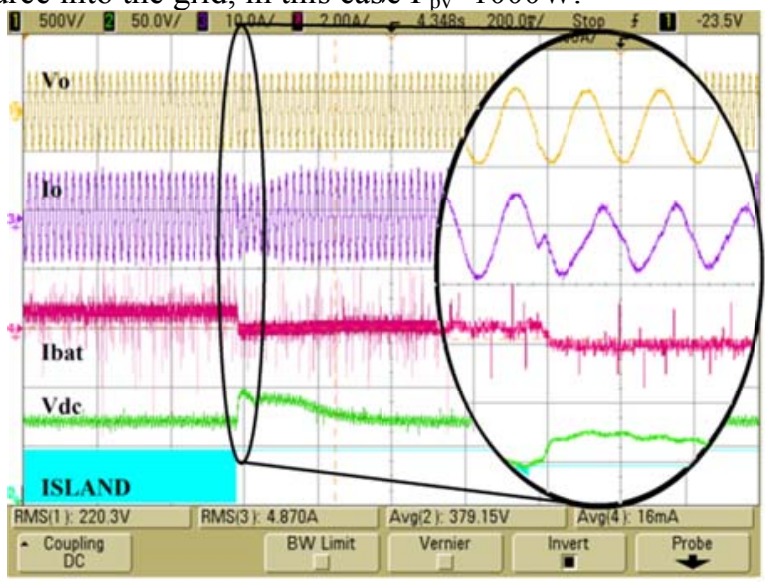

Fig. 22. Experimental results of the transition from island mode to grid connected mode after synchronization of the inverter output voltage and the 
grid voltage. Inverter output voltage (Vo, 500V/div) and inverter output current (Io, 10A/div), output battery current (Ibat, 1A/div), DC-link voltage

(Vdc 20V/div), and islanding signal (ISLAND). Time scale $=200 \mathrm{~ms} / \mathrm{div}$.

\section{CONCLUSIONS}

A photovoltaic power management system with battery backup capable of both islanded and grid-connected operation is studied in this paper. The system is based on a battery side DC/DC converter connected to the DC-link of the PV inverter. The control of the DC-link voltage is performed by the DC/DC converter in islanded operation and by the inverter in grid-connected mode. The MPPT algorithm provides the DC-link voltage reference for either of the power converters. Only a part of the generated power is processed by the $\mathrm{DC} / \mathrm{DC}$ converter. The power flow in the batteries and their charge level is controlled by the DC/DC converter.

The transition between grid-connected and island mode and vice versa is implemented by means of a reconfiguration of controllers. In grid-connection mode, the inverter is controlled as a current source in phase with the grid voltage. When the inverter becomes isolated from the grid, the inverter changes its control configuration, working as a voltage source and using the droop method to feed the local loads. The batteries provide the supplementary power to the loads if the PV available power is insufficient.

The main operational aspects of the system were verified by means of simulations and experimental results.

\section{REFERENCES}

[1] REN21 Steering Committee, "Renewable 2009, Global Status Report", Worldwatch Institute Washington, DC, 2009.

[2] H.B Puttgen, P.R. MacGregor, and F.C. Lambert, "Distributed generation: Semantic hype or the dawn of a new era?", Power and Energy Magazine, IEEE, Jan-Feb 2003, vol.1, no.1, pp. 22-29.

[3] Y. Zhu, Z. Yin, J. Tian, "Microgrids Based on DC Energy Pool," Energy 2030 Conference, 2008. ENERGY 2008. IEEE, pp.1-2, 17-18 Nov. 2008.

[4] B. Belvedere, M. Bianchi, A. Borghetti, M. Paolone, "A microcontroller-based automatic scheduling system for residential microgrids," PowerTech, 2009 IEEE Bucharest, pp.1-6, Jun. 2009.

[5] C. Sudipta, W. Manoja, M. Godoy, "Distributed Intelligent Energy Management System for a Single-Phase High-Frequency AC Microgrid," Industrial Electronics, IEEE Transactions on, vol.54, no.1, pp.97-109, Feb. 2007.

[6] T. Selim, C. Ozansoy, A. Zayegh, "Recent developments in microgrids and example cases around the world-A review," Renewable and Sustainable Energy Reviews, vol.15, issue 8, pp.4030-4041, Oct. 2011.

[7] Y.M. Chen, H. Wu, Y.C. Chen, K. Y. Lee, S. S. Shyu, "The AC Line Current Regulation Strategy for the Grid-Connected PV System," IEEE Trans. on Power Electronics, vol.25, no.1, pp.209-218, Jan. 2010 .

[8] M. Ciobotaru, R. Teodorescu, F. Blaabjerg, "Control of single-stage single-phase PV inverter, Power Electronics and Applications", 2005 European Conference on, 2005, pp.-P.10.

[9] J.M. Guerrero, J.C. Vasquez, J. Matas, M. Castilla, L.G. de Vicuna, "Control Strategy for Flexible Microgrid Based on Parallel LineInteractive UPS Systems", Industrial Electronics, IEEE Transactions on, vol.56, no.3, pp.726-736, March 2009

[10] K. Jaehong, J.M. Guerrero, P. Rodriguez, R. Teodorescu, N. Kwanghee, "Mode Adaptive Droop Control With Virtual Output Impedances for an Inverter-Based Flexible AC Microgrid," IEEE Trans. on Power Electronics, vol.26, no.3, pp.689-701, March 2011.

[11] I.J. Balaguer, L. Qin, Y. Shuitao, U. Supatti, Fang Zheng Peng, "Control for Grid-Connected and Intentional Islanding Operations of Distributed Power Generation,” IEEE Trans. on Industrial Electronics, vol.58, no.1, pp.147-157, Jan. 2011.

[12] C.L. Chen; Y. Wang; J.S. Lai; Y.S. Lee, D. Martin , "Design of Parallel Inverters for Smooth Mode Transfer Microgrid Applications",
Power Electronics, IEEE Transactions on , vol.25, no.1, pp.6-15, Jan. 2010

[13] K. Hyosung, Y. Taesik, C. Sewan, "Indirect Current Control Algorithm for Utility Interactive Inverters in Distributed Generation Systems," IEEE Transactions on Power Electronics, vol.23, no.3, pp.1342-1347, May 2008.

[14] M.A. Hassan, M.A. Abido, "Optimal Design of Microgrids in Autonomous and Grid-Connected Modes Using Particle Swarm Optimization," IEEE Transactions on Power Electronics, vol.26, no.3, pp.755-769, March 2011.

[15] I. Serban, C. Marinescu, "A look at the role and main topologies of battery energy storage systems for integration in autonomous microgrids," Optimization of Electrical and Electronic Equipment (OPTIM), 2010 12th International Conference on , vol., no., pp.11861191, 20-22 May 2010

[16] I.Serban, C. Marinescu, "Active power decoupling circuit for a single-phase battery energy storage system dedicated to autonomous microgrids," Industrial Electronics (ISIE), 2010 IEEE International Symposium on , vol., no., pp.2717-2722, 4-7 July 2010

[17] M.A. Sofla, L. Wang; , "Control of DC-DC bidirectional converters for interfacing batteries in microgrids," Power Systems Conference and Exposition (PSCE), 2011 IEEE/PES , vol., no., pp.1-6, 20-23 March 2011

[18] I. B. Song; D. Y. Jung; Y. H. Ji; S. C. Choi; S. W. Lee; C. Y. Won, "A residential 10kWh lithium-polymer battery energy storage system," Power Electronics and ECCE Asia (ICPE \& ECCE), 2011 IEEE 8th International Conference on , vol., no., pp.2625-2630, May 30 2011June 32011

[19] G. Y. Choe; J. S. Kim; B. K. Lee; C. Y. Won; T. W. Lee, "A Bidirectional battery charger for electric vehicles using photovoltaic PCS systems," Vehicle Power and Propulsion Conference (VPPC), 2010 IEEE, vol., no., pp.1-6, 1-3 Sept. 2010

[20] R. Gules, J. De Pellegrin Pacheco, H.L. Hey, J. Imhoff, "A Maximum Power Point Tracking System With Parallel Connection for PV StandAlone Applications," Industrial Electronics, IEEE Transactions on vol.55, no.7, pp.2674-2683, July 2008.

[21] J.C. Vasquez, J.M. Guerrero, A. Luna, P. Rodriguez, R, Teodorescu, "Adaptive Droop Control Applied to Voltage-Source Inverters Operating in Grid-Connected and Islanded Modes," IEEE Trans. on Industrial Electronics, vol.56, no.10, pp.4088-4096, Oct. 2009.

[22] J.M. Guerrero, J. Matas, L.G. de Vicuna, M. Castilla, J. Miret, "Wireless-Control Strategy for Parallel Operation of DistributedGeneration Inverters," IEEE Trans. on Industrial Electronics, vol.53, no.5, pp.1461-1470, Oct. 2006.

[23] W. Yao, M. Chen, J. Matas, J.M. Guerrero, Z. M. Qian, "Design and Analysis of the Droop Control Method for Parallel Inverters Considering the Impact of the Complex Impedance on the Power Sharing," Industrial Electronics, IEEE Transactions on , vol.58, no.2, pp.576-588, Feb. 2011

[24] T. Esram, P.L. Chapman, "Comparison of Photovoltaic Array Maximum Power Point Tracking Techniques", Energy Conversion, IEEE Transactions on, vol.22, no.2, pp.439-449, June 2007.

[25] N. Femia, G. Petrone, G. Spagnuolo, and M. Vitelli, “A Technique for Improving P\&O MPPT Performances of Double-Stage GridConnected Photovoltaic Systems," IEEE Trans. On Industrial Electronics, vol.56, no.11, pp.4473 - 4482 , Nov. 2009.

[26] N. Mohan, T. Undeland, W. Robbins, "Power electronics: converters applications, and design", John Wiley \& Sons, 1995.

[27] M. Liserre, F. Blaabjerg, R. Teodorescu, Z. Chen, "Power converters and control of renewable energy systems", ICPE 2004, Busan, Korea, Invited paper.

[28] D. Velasco, C. Trujillo, G. Garcera, E. Figueres, "An active Antiislanding method based on phase-PLL perturbation", Power Electronics, IEEE Transactions on, vol.PP, no 99, pp. 1-1, October 2010

[29] M. Ciobotaru, R. Teodorescu, F. Blaabjerg, "A new singlephase PLL structure based on second order generalized integrator", Record of IEEE PESC 2006, Jeju, Korea, p. 1511-1516.

[30] M. Liserre, A. Timbus, R. Teodorescu, F. Blaabjerg, "Synchronization methods for three phase distributed power generation systems. An overview and evaluation", PESC 2005, Recife, Brasile.

[31] N. Femia,, G. Petrone, G. Spagnuolo, M. Vitelli, "Optimization of perturb and observe maximum power point tracking method, Power Electronics, IEEE Transactions on, vol.20, no.4, pp. 963- 973, July 2005

[32] IEEE recommended practice for grid interface of photovoltaic (PV) systems, IEEE Std. 929, 2000

[33] Guoqiao Shen, Xuancai Zhu, Jun Zhang, and Dehong Xu, "A New Feedback Method for PR Current Control of LCL-Filter-Based Grid- 
Connected Inverter," IEEE Trans. on Industrial Electronics, vol.57, no.6, pp.2033-2041, June 2010.

[34] T. Thacker, F. Wang, D. Boroyevich, "Islanding Control of a Distributed Generation Unit's Power Conversion System to the Electric Utility Grid", Power Electronics Specialists Conference, 2005. PESC '05. IEEE 36th, June 2005, pp.210-216.

[35] PSIM 7.0 User's Guide. 2006, Powersim Inc., March 2006

[36] J.M. Guerrero, L.G. de Vicuna, J. Matas, J. Miret, M. Castilla, “A wireless controller for parallel inverters in distributed online UPS systems," Industrial Electronics Society, 2003. IECON '03. The 29th Annual Conference of the IEEE, vol.2, no., pp. 1637- 1642, Nov. 2003 